\title{
Understanding Communicative Needs of Second Language Learners in Undergraduate Colleges
}

\author{
VidyaPai $C^{1}$, KarunakaranB. Shaji ${ }^{2}$ \\ ${ }^{1}$ (Research Scholar, Dept. of English, Bharathiar University, India) \\ ${ }^{2}$ (Research Supervisor, Bharathiar University \&Asst. Prof., Dept. of English, Regional Institute of Education, \\ Mysuru, India)
}

\begin{abstract}
For years the English proficiency of Second Language Learners in colleges especially in the rural areas is constantly declining. The medium of instruction and therefore the execution of the mother tongue education is most often the reason attributed to this. The study makes an effort to view the current situation prevalent in some of the colleges locatedaround Mysuru city, Karnataka (a state in India). It aims at examining the learning environment and perceptions of students towards English language learning while highlighting the shift needed from studying English Language as a subject, to learning English as a medium of communication \& expression.
\end{abstract}

Key words:Communicative approach, Communicative competence, Comprehensible input, Learning environment, Second Language Learners.

\section{INTRODUCTION}

Any "language is best learnt when it is taught as a means of communication" (Alam, 1999:16). English language is no exception. "The study of English language is primarily the study of the process of how to communicate something to somebody with the maximum clarity and effect that is best suited to a particular situation (Alam, 1999:16). Surprisingly, 'English teaching' in undergraduate colleges around Mysuru city, which rolls out hoards of graduates in Management, Commerce \& Arts year after year,has not received this impetus. English language, as is the practice is taught by exposing the student to literary pieces of English prose, poetry, drama \& fiction. The existing syllabus and approach practiced in English teaching-learning has resulted in a situation where students spend more time on the literary content in the text book than use the language to communicate. The consequence is that new graduates from these colleges face serious problem in English. They have insufficient English proficiency for purposes of higher studies and are not acquainted with English which has become a vitalprerequisitein the world of business. Such graduates because of their low English proficiency lose to applicants with better communicative abilities.

The demand for English is now greater than ever in India. From being the link language and associate official language, English is fast acquiring a new status. It is a language sought after by the urban middle class who view English as a powerful agent of growth both in their professional as well as their personal lives (Graddol, D (2010). Though the study of English has been a part of our formal study for a good number of years, its access outside its urban boundaries has been less effective. This has resulted in a great divide in language between the urban and the rural- a gap between the English literate and the English illiterate population in rural areas in India. The important thing then, is to empower the rural learners so that they do not remain forever disadvantaged in areas of English based higher education and in terms of social mobility.Many educated Indians for whom English is more a first language, have expressed serious concerns about not much being done in most colleges and universities to improve communication ability of students. The study makes an effort to view the current situation prevalent in some of thecolleges around Mysuru city. It aims at highlighting the shift needed from studying English Language as a subject, to learning English for communication \& expression.Keeping in mind the fact that language classrooms are complicated places making it difficult for any researcher, the study tries to examine the relationship between the dependent variable of language proficiency and independent variables such as method, materials, learner environment, learners' background, previous study of English, anxiety \& confidence levels etc.

\subsection{Background to the study}

The English teaching- learning scenario in colleges located in rural areas strengthens the need for a shift in focus.English in most colleges located in rural areas is studied as 'Second Language' (for two years) while the regional language is the medium of instruction. As a result the learner in a rural college studies English merely as a subject which is to be cleared for the award of the degree. In other words, it is studied like 
history, sociology or any other subject. The status of English then is restricted only to that of 'classroom study' and is limited only to the few hours of the week allotted to the study.

English Teaching over the years has been through the use of an 'Anthology of Prose \& Poetry' aimed at developing aesthetic sensibility and enhancing the sense of appreciation for the language. Shakespeare's plays like Julius Caesar, Macbeth, The Merchant of Venice are even now prescribed for students "who do not even know the rudiments of modern English usage" (Alam, 1999).

The student's understanding of the text is limited to memorizing the narrative and a few character sketches without reading the text prescribed or understanding the structures, linguistic forms or lexicon. The result is that most students are able to reproduce notes on literary topics but are not well equipped for using English for transactional purposes. Such practices only encourage students to learn by rote instead of honing their intellectual and analytical abilities. The prevalent condition is best explained in the words of Verghese (1989, p.16) when he says, "As far as the foreign learner is concerned, the history of language teaching shows emphasis on a very limited range of competence which has been called 'classroom English' or 'textbook English' and has often proved less than useful for any 'real' communicative purpose". His observation parallels those of R.E Underwood, the British Council expert, who speaking about the level of English proficiency of a student in Indian universities, at the Nagpur session of the All India English Teacher's Conference, said, "Today's University English education has resulted in a situation where the average college student cannot write acceptable English, cannot understand spoken or written English \& is very slow at reading. He is the outcome of the college text which contains passages not primarily selected for the purposes of language learning and development of reading skills; contains no glossary and no text-based remedial language exercises". (Alam, 1999:4-5)

As a matter of fact, explanation to various literary works which are prescribed is through paraphrasing or translation into the regional language depriving, the learners of the small exposure to English they are entitled to. Added to this is the fact that most learners come from a family background where they form the first generation learners, where homes do not provide a learning environment.

\subsection{Aim of the study}

1. To investigate the reasons for low proficiency in English of students studying in colleges located in rural areas

2. To examine the learning environment and perceptions of students towards English language learning

3. To shift the emphasis of English studies from the subject to the learner

4. To recommend an approach which would help learnersattain not only context restricted and syllabus bound competence of English but also acquire a certain level of communicative competence which will enable \& empower them to the roles that they have to play in a variety of situations.

\section{LITERATURE REVIEW}

This section is divided into two parts. Part I traces a brief history of English Language Teaching in India and the position of English in India today. Part II summarizes the need for a communicative approach to language teaching.The section collates the opinion of experts in the field, academicians \& researchers. The sources of this study include books, articles, online journals and previous researches conducted in related areas. QaizerZohaAlam's book English Language Teaching: Problems and Issues (1999) provide a very intricate and impressive account of English from the time of its introductionin India to its current status in colleges. He points out howthe study of English was an important part of the liberal and humanistic discipline when the British introduced the modern system of English education in India, over a hundred years ago. The teaching of English followed a set pattern, with the University of London providing the model. However, the focus of ELT and the position ofEnglish as a language in our educational system have been changing over the years.

Distraught at the rapid decline in academic standards in all subjects especially English, the Calcutta University Commission stressed the importance of the study of English as part of general education in India.Absence of native speakers of English as instructors,inaptness of teaching techniques and lack of methodical instruction in spoken English were thought by the Commission, to be some of the causes for the drop in the quality of the teaching of English.

A major setback which further weakened the standards of teaching and learning of English during the 30s was when the regional languages were made the medium of instruction, resulting in an inadequate exposure to the English language. Unrealistic examination systems, extraneoustext books resulted in further decline. A need for the rationalization of the English curricula, textbooks and examinations was strongly felt by a number of commissions \& study groups. The functional nature of English was realized which resulted in a need for diversification of the courses to suit the divergent requirements of students from different streams. Nevertheless, the importance of English continued to be underlined by both Radhakrishnan Commission (1948) \& the Kunzru committee (1955). 
In the coming years, various thinkers \& reports of committees laid great emphasis on the study of literary works in the teaching of English as Second Language. Pattison, Holloway, Gokak are a few to name. However, Jo McDonough's (1977) argument that the role and status of literary study should depend on a careful analysis of learners needs, gave rise to a new line of thought and discussion. The focus on English teaching was shifted to teaching of language rather than on literature. The language through literature series prepared at Central Institute of English \& Foreign Languages, Hyderabad, is an apparent example.

Jain (1974) explained how several imperatives have, since independence, dictated why English should be taught and learnt in India- the status imperatives, the political imperative, the commercial imperative, the cultural imperative and the academic imperative. According to him, "We should learn English for academic purposes. It amounts to learning English at a very competent level. And there is no short cut to it" (Alam, p.7.) Accordingly, the courses after 1975 have largely concentrated on the functional \& communicative aspects keeping the learner's need in mind.

Today, as Graddol (2010) points out, English has become a world language rather than the language of only the English speaking countries because the number of the people who use English as a means of communication exceeds the number of the people who speak it as their mother tongue. Also, the process of economic and social development has changed the role of English in India. As a result, a major shift, with English being used by more people, for more purposes than ever before is underway in India:

"There are three main drivers in India towards the greater use of English: education (increasing demand for English-medium schools, widening access to higher education, incorporation of English training in vocational education); employment (many jobs in the organized sector now require good English skills); social mobility (English is seen as an access route to the middle classes and geographical mobility within India and beyond)" (Graddol, 2010, p.14)

According to the 2015 English Proficiency Index (EPI), the nations (from among 18 countries from Asia) found to have the highest levels of English language proficiency, were Singapore, Malaysia and India.While acknowledging the great improvements that Asia has experienced, the EPI report also makes the point that though Asia has excelled in Mathematics and Science, English language teaching across the region is generally low and greater effort in English language instruction is needed to increase the region's global competitiveness.

Though India has jumped (to higher)places in the English Proficiency Index (EPI), the country can boast of an enhanced proficiency only when English learning is better accessed in rural India from where major part of our workforce is obtained. Unfortunately, language classes for a long time now have been stressing the importance of writing than speaking. Our examination system assesses students on their ability to write and reproduce the literary content made available to them and our textbooks do not contain exercises for practice of oral skills leaving the communicative abilities of students in a highly deplorable state. While English teachinglearning will always remain a debatable issue, it would be a significant move by the members of board of studies in universities, eminent academicians \& concerned authorities to shift the emphasis of English studies from the subject to the learner through the use of methods \& approaches which will enhance students' ability to communicate in real time situations.

\subsection{What is CLT?}

Communication for second / foreign language teachers, as Savignon (1991), in her State of Art paper points out, was understood in terms of the fourlanguage skills: listening, speaking, reading and writing. These skills were together referred to as 'active' skills which involved speaking \& writing and 'passive' skills for reading \&listening. But today, listeners and readers are seen actively participating in the negotiation of meaning, and are no longer regarded as passive. Subsequently, these categories were described as 'productive' skills needed to engage in speaking \& writing and as 'receptive' for skills needed for listening \& reading. Shortly afterwards, the ineffectuality of a four skills model of language was realized. The need for second language learners to use language for communication to participate in the negotiation of meaning was felt more than ever. "The communicative competence needed for participation included not only grammatical competence, but pragmatic competence" (1991:263). CLT was the result of a worldwide shift in 1970s in language teaching which emphasised communication as the fundamental reason for language teaching. It redefined language learning in terms of communicative competence rather than linguistic competence. To put it more simply, it advocated teaching communication through language (Cook, 2008). While accepting the view that communication is the rightaim of language teaching, Allwright (1977) raises a very pertinent question of whether we teach language for communication, or we teach communication through language.Explaining the relationship between communicative competence and linguistic competence, he points out that instruction intended for linguistic competence alone will essentially leave a hugepart of communicative competence untouched whereas teaching communicative competence will certainlysatisfy all but a small part of linguistic competence.So, if communication is to be taken as the major aim of language teaching it would be advisable to focus on communicative skills. 
For Littlewood (1981), communicative approach considers language not only in terms of its structures, but also in terms of the communicative functions that it performs. This newer practical view of language can therefore be combined with theconventional view in order to achieve a more complete communicative standpoint.

Consistent with the view of language as a means of communication, Newmark $(1966$, p.162) points out that the "aim of language teaching is not saying and understanding what we want but saying with understanding. That is, we want the learner to be able to use the language we teach him, and we want him to be able to extend his ability to new cases, to create new utterances that are appropriate to his needs as a language user".

For Wilkins (1972, p.90), "the aim of language teaching is to teach learners to exploit their grammatical (and lexical) knowledge in creative acts of communication".

For decades now, English language teachers have been baffled by the problem of the student who may be 'structurally competent' but who cannot 'communicate appropriately' (Johnson, 1979). This kind of teaching results from a practice based on the belief that "one is providing for some future use by developing a stock of grammatical competence which will be immediately converted into adequate performance when need arises" (Widdowson, 1973 p.49-50).For Widdowson (1978: 67), the issue is not whether acquiring communicative competence is the aim of language learning; the issue is about how this aim is to be achieved. It is generally supposed that once language skills are acquired in reasonable measure, communicative abilities will follow in automatic consequence. But evidence suggests that acquisition of language skills does not seem to assure the subsequent acquisition of communicative capabilities in a language.

The study therefore, is an attempt to highlight an approach which would help learners attain not only context restricted and syllabus bound competence of English but also acquire a certain level of communicative competence which will enable \& empower them to the roles that they have to play in a variety of situations.

\section{METHODOLOGY AND PROCEDURE}

The main aim of the study is to test the level of English proficiency of undergraduate students of Commerce, Management \& Arts discipline. The objective of the study is to highlight the shift from English studied as a subject to a study of language as a means of communication and expression. Data for the study was collected through administration of questionnaire comprising both close ended and open ended question.

\subsection{Population and Sampling}

Three colleges located in rural areas around city of Mysuru, (Karnataka state, India), were selected for the study. The three colleges identified for the study were selected based on their rural connectivity. The sample of 396 respondents comprised students enrolled in the first year study of B Com, BBM and BA from the three selected colleges.

\subsection{Instrument}

The data required for the study was collected directly from respondents in three colleges. The only instrument used for this study was a questionnaire administered to students, a subject-based instrument, i.e., it was to be filled by the subjects themselves. The questionnaire consisted of five sections:

Section I covered the demographic details of the learners- their names, age, class to which they belong, father's occupation, their medium of study, educational background \& mother tongue.

Section II(only items 3, 4, 5, $6 \& 10,11,12,13$ are considered for this study) required respondents to tick Yes/ No to items 1-15 indicating their confidence level, attitude towards language, learning environment etc.

Section III \& IV were the grammar items 16-24 and comprehension items 25-30 respectively. This section provided the researcher with the current competence of respondents in grammar \& comprehension.

Section V (item 30) was an open ended question to gather their views on the role of English in professional success.

The respondents though with a minimum of seven years of formal English education had difficulty in comprehending the questions. The data collected was analysed and tabulated. The interpretation of the data was done by percentages and bar graphs. 


\subsection{Analysis}

\subsubsection{Section I}

\begin{tabular}{|c|c|c|c|c|c|}
\hline \multicolumn{6}{|c|}{ Table 1 - Demographic details } \\
\hline & Details & College 1 & College 2 & College 3 & \multirow[t]{2}{*}{ Percentage } \\
\hline & Age & $17-19$ & $17-19$ & $17-19$ & \\
\hline \multirow[t]{2}{*}{ Gender } & Male & 0 & 70 & 58 & $32 \%$ \\
\hline & Female & 122 & 110 & 36 & $68 \%$ \\
\hline \multirow{2}{*}{$\begin{array}{l}\text { Father's } \\
\text { occupation }\end{array}$} & Agriculture & 45 & 172 & 88 & $77 \%$ \\
\hline & Others & 77 & 8 & 6 & $23 \%$ \\
\hline \multirow{3}{*}{$\begin{array}{l}\text { Class in which } \\
\text { studying }\end{array}$} & BBM & 0 & 36 & 0 & $9 \%$ \\
\hline & B Com & 122 & 89 & 61 & $69 \%$ \\
\hline & BA & 0 & 55 & 33 & $22 \%$ \\
\hline \multirow{2}{*}{$\begin{array}{l}\text { Medium of } \\
\text { study }\end{array}$} & English & 47 & 0 & 0 & $12 \%$ \\
\hline & Kannada & 75 & 180 & 94 & $88 \%$ \\
\hline \multirow[t]{2}{*}{ Mother tongue } & Kannada & 120 & 180 & 94 & $99.50 \%$ \\
\hline & $\begin{array}{l}\text { Other } \\
\text { languages }\end{array}$ & 2 & 0 & 0 & \\
\hline \multirow{3}{*}{$\begin{array}{l}\text { Background of } \\
\text { study }\end{array}$} & CBSE & 0 & 0 & 0 & \\
\hline & ICSE & 0 & 0 & 0 & \\
\hline & $\begin{array}{l}\text { State Pre- } \\
\text { University } \\
\text { board }\end{array}$ & 122 & 180 & 94 & $100 \%$ \\
\hline
\end{tabular}

It is said that India lives in its villages, where agriculture is the major occupation. $77 \%$ of the respondents come from an agricultural background forming the first generation learners in their families. A small number, $23 \%$ of students come from families which belong to the economically weaker sections of society. Many of them are largely constrained by economic conditions and cannot afford education in cities. The Government's effort in setting up of colleges and making education available in rural areas(at subsidized rates and with scholarships) is extremely laudable. Most students selected for the study fall in the age group of 17-19, selected from three undergraduate programmes - Bachelor of Commerce, Bachelor of Business Management \& Bachelor of Arts. $88 \%$ have opted for a vernacular medium and 99.5\% speak the regional language (Kannada) as their mother tongue.The composition of these classes provides a heterogeneous mix comprising both highly talented students as also students who are highly unfocussed. Common to both is lack of communication \& expression and a total lack of exposure to the world outside. The study of English as second language is to be viewed against this background. The three colleges selected for study are Government First Grade College for Women, Belvadi; Government First Grade College, Saligrama; and Government First Grade College,Billikere; located approximately 10 kilometres, 70 kilometres\& 30 kilometres respectively from the city of Mysuru, Karnataka state.

\subsubsection{Section II}

Table 2 - Attitude towards Language Learning

\begin{tabular}{|l|l|r|r|}
\hline \multicolumn{2}{|l|}{} & Yes & No \\
\hline Q. 3 & Do you find English difficult to learn? & $37 \%$ & $63 \%$ \\
\hline Q.4 & Do you like learning English? & $99 \%$ & $1 \%$ \\
\hline Q. 5 & Do you feel learning to speak in English is important? & $98 \%$ & $2 \%$ \\
\hline Q.6 & Do you enjoy English classes? & $88 \%$ & $12 \%$ \\
\hline
\end{tabular}

Language learning, according to many theorists, is affected by attitude and motivation. Merriam Webster dictionary defines attitude as the way we think and feel about someone or something. According to Dulay and Burt, (as cited in Horwitz, 1986) learner attitudes and motivation acts as an "affective filter" through which the target language must pass. While positive attitude makes students receptive to language acquisition experiences, students with negative attitude have a less permeable affective filter and thereby close themselves off from listening and reading in a second language. Applying this to the data gathered for items-3,4,5,\& 6 , the attitude of students towards language learning is positive with only $37 \%$ of respondents expressing difficulty in learning the language; a large majority holding the view that learning to speak in English is important, while enjoying English classes.

\subsubsection{Table 3 - Learning Environment}

\begin{tabular}{|c|c|c|c|}
\hline & & Yes & No \\
\hline Q.10 & Do you speak English outside your class hours & $24.50 \%$ & $75.50 \%$ \\
\hline Q 11 & Do you borrow English books for general reading from the library & $27.50 \%$ & $72.50 \%$ \\
\hline Q.12 & Do you read English newspaper every day? & $20 \%$ & $80 \%$ \\
\hline Q.13 & Do you listen to English news on radio or TV? & $53 \%$ & $47 \%$ \\
\hline
\end{tabular}


For years the English proficiency of Second Language Learners in universities \& colleges, especially those located in rural areas, has been fast declining. The reasons most often attributed to this is the medium of instruction and therefore the execution of mother tongue education.But very rarely have people thought of the relationship between declining English ability and the prevalent learning environment.

Stephen Krashen's Acquisition / learning hypothesis, claims that there are two distinct ways of developing competence in a second language. Acquisition according to him is the 'natural' way, similar to first language development in children. In contrast, Learning denotes a process by which the conscious rules of a language are developed (Richards and Rodgers, 2001: 181). Whether language learning happens through acquisition or learning, one thing is for certain. Learners learn a language only when exposed to it. So, one of the important conditions of learning a second language is abundant exposure to it. But unfortunately learners are not as much and as constantly exposed to the target language in the same way as they were exposed to their mother tongue. As D. A. Wilkins observes, "One year in the classroom provides the equivalent of from one to three weeks' contact in a language -acquisition situation". He adds: "If it takes from three to four years for a child to learn his mother tongue to a reasonable degree of proficiency, we can work out for ourselves the astronomical length of time it would take for language learning to reach the same level if it was based on the same kind of largely random exposure to language" (Verghese. P, 1989:20). The only way one can get over this 'random exposure' to language is by motivating students to read \& listen to more of English through exposure to English newspapers, magazines, books, news on television \& radio, encourage the use of target language beyond class hours, organize guest lectures etc., all these contribute to an informal learning environment, while the classroom provides a formal environment through the curriculum.

It is a known fact that the access of English outside its urban boundaries has been rather ineffective. Language teaching in most of these colleges happens through the lecture method. In a rural setup, the English teacher is often (almost always) forced to resort to extensive mother tongue usage. In other words explanation of various literary pieces is through translation or paraphrasing. Language teaching-learning is mainly focussed on the completion of portions from the prescribed text and providing the students with explanatory notes which they reproduce in the examination, which makes for a system of insufficient assessment of only the writing skills of these learners. Going by the traditional approach of learning a language in terms of the four skills, LSRW, the current pattern of examination helps assess only writing skills.

A common problem which requires immediate attention is the large size of classes in these areas. This makes it highly impossible for language teachers to engage them in any pair or group activity. No attention is paid to enhancing the reading strategies of the learners such as skimming, browsing \& scanning. Under these circumstances, can students learn a language? Do they really move from one point to another? The question is best explained by Stephen Krashen's Input Hypothesis. "Second languages are acquired by understanding messages or by receiving comprehensible input"(Krashen, 1985:2). For Krashen, 'comprehensible input' meant the bit of language that is heard or read and that which is slightly higher than the learners' current state of grammatical knowledge. A learner does not have the ability to do anything with structures he already knows or with those structures way ahead of his current knowledge. Krashen defined a learner's current state of knowledge as ' $i$ ' and the next stage as ' $i+1$ '. Thus the input a learner is exposed to must be ' $i+1$ ' level in order for it to be of use in terms of acquisition (Krashen 1985, p.2 as cited in Gass and Selinker 2008, p.309).

Applying this to the classroom scenario, the teacher's lecture is the only source of comprehensible input, which sadly enough provides no interaction or exposure to the target language. Equally deplorable is their condition with respect to vocabulary. Only $24.5 \%$ of respondents claim that they use the target language outside their class hours \& $72.5 \%$ do not borrow books in English for general reading. Any skill whether speaking or reading can be acquired only through practice. A dedicated teacher can at best motivate the practical use of the language, i.e., create an opportunity for the students. It is the student who has to understand the communicative need of the target language and put it to use in real time situations.Newspapers which are rightly called 'The mirrors of the world' reflect and report the events which happen all over the world. The role of newspapers in L2 learning in terms of learning expressions \& vocabulary cannot be ruled out. Improved literacy rate in India has resulted in increase in the circulation of regional language newspapers. A large majority of (80\%) respondents do not read English newspaper on a daily basis, depriving them of that little exposure to target language. This clearly indicates that the learning environment lacks reinforcement of what is learnt in the classroom. Absence of interactive sessions because of the methodology adopted, large size of classes and prevalence of a culture, dominated by mother tongue, will both, inhibit learners as well as impede language learning.

As Nunan (1991), in his paper titled "Communicative Tasks and the Language Curriculum", points out, "syllabus design is concerned with the destination, while methodology is concerned with the route". Unfortunately, in the context of rural learners, neither the destination nor the route neither the syllabus design nor the methodology have helped facilitate second language learning, nor helped students fulfil their real world needs in terms of improved communicative \& interactive skills, leaving them highly disadvantaged in areas of higher education and employment. 
Summarising the results so far, it is clear that different variable factors such as age, attitude, background study, learning environment etc. influence language learning and impact it differently. But, as Verghese (1989) points out, "of all the factors, the learning environmentwhich comprises classroom atmosphere, teaching methods, aids \& materials, the knowledge, preparedness, personality of the teacher, persuasiveness and perseverance of the teacher, etc., is the one that can be manipulated most".

\section{CONCLUSION}

Most jobs for graduates today are based on their ability to express and communicate well. Graduates who are technically strong but communicatively weak lose to candidates with better communication in their race for employment. The goal of second language learning, then, should be to develop communicatively competent students who can communicate effectively in real life situations. A communicatively competent second language learner is not one who is able to understand and appreciate prose \& poetry pieces explained to him in L1, which he reproduces through the explanatory notes of the teacher; but one who can extend the learning of L2to the reading and subsequent understanding of literature in the target language; one who can develop pragmatic competence by using the language learnt for practical needs. This needs both a communicative \& committed approach by teachers. The application of this approach which will lead the second language learner to communicative competence is not the prerogative of urban learners alone, nor is it restricted to those fortunate colleges with comparatively small classes. The successful implementation of a communicative approach has less to do with the size of classes and more to do with facilitation of the right learner environment, attitude and most importantly the willingness of those involved- the teacher and the taught; the facilitator and the facilitated. Any change in the prevalent situation is possible only if the new approach to language teaching,as Nunan (1991) points out, lays emphasis on interaction in the target language, use of authentic texts, focuses on both product (language learnt) as well as process (methodology adopted), while attempting toassociate language taught in classrooms with language practise outside the classroom.

\section{REFERENCES}

[1] Alam, QaiserZohaEnglish Language Teaching in India: Problems and Issues(New Delhi: Atlantic, 1999) Print. p 1-16

[2] Graddol, D, English Next India(British Council, 2010) p.14

[3] Verghese, Paul Teaching English as a Second Language (New Delhi: Sterling, 1989) p 16, 20, 37

[4] Maxwell, Daniel. (2015, Nov 6) English Proficiency Index 2015: Mixed results across Asia.Asiancorrespondent.com, English-proficiency-index-2015- Retrieved 15 Nov, 2015

[5] Savignon, Sandra, Communicative Language Teaching: State of the Art TESOL Quarterly25 (2) 1991: 261-277. Print.

[6] Cook, Vivian Second Language Learning and Language teaching $4^{\text {th }}$ ed (London: Hodder Education, 2008).

[7] Allwright, Richard Language Learning through Communication Practice. In: Brumfit and Johnson (eds.), The Communicative Approach To Language Teaching (Oxford: Oxford University Press, 1983)

[8] Littlewood, W. Communicative Language Teaching: An Introduction (Cambridge: Cambridge University Press, 1981)

[9] Newmark, Leonard How not to interfere with Language Learning. In: Brumfit and Johnson (eds.), The Communicative Approach To Language Teaching (Oxford: Oxford University Press, 1983)

[10] Wilkins, D.A Grammatical, Situational and Notional Syllabus. In: Brumfit and Johnson (eds.), The Communicative Approach To Language Teaching(Oxford: Oxford University Press, 1983)

[11] Johnson, Keith Communicative approaches and Communicative processes. In: Brumfit and Johnson (eds.), The Communicative Approach To Language Teaching (Oxford: Oxford University Press, 1983)

[12] Widdowson, H.G, Directions in the Teaching of discourse. In: Brumfit and Johnson (eds.), The Communicative Approach To Language Teaching (Oxford: Oxford University Press, 1983)

[13] Widdowson, H.G Teaching Language as Communication (Oxford: Oxford University Press, 1978)

[14] Horwitz, Elaine K, Some Language Acquisition Principles and Their Implications for Second Language Teaching, Hispania 69 (3), 1986, 684-689.

[15] Richards, Jack C., and Theodore S. Rodgers Approaches and Methods in Language Teaching. $2^{\text {nd }}$ ed. (Cambridge: Cambridge University Press, 1986) p 181

[16] Gass, Susan M., and Larry SelinkerSecond Language Acquisition: An Introductory Course. $3^{\text {rd }}$ ed (New York: Routledge, 2008) p 309

[17] Nunan David, Communicative tasks and Language Curriculum,TESOL Quarterly 25 (2) 1991, 279 - 295 